\title{
POTENSI MADU DALAM MENINGKATKAN KUALITAS MINUMAN KEFIR
}

\author{
Analysis of Honey Addition to Improve Kefir Drink Qualities \\ Yurliasni $^{1)}$, Zuraida Hanum ${ }^{1)}$ dan Ridha Hikmawan ${ }^{2)}$ \\ 1) Program Studi Peternakan, Fakultas Pertanian, Universitas Syiah Kuala, Banda Aceh, 23111, Indonesia \\ ${ }^{2)}$ Mahasiswa Program Sarjana, Program Studi Peternakan, Fakultas Pertanian, Universitas Syiah Kuala, Banda \\ Aceh, 23111, Indonesia \\ E-mail: yurliasni62@gmail.com
}

Diterima 9 Desember 2018 ; diterima pasca revisi 15 Maret 2019

Layak diterbitkan 1 April 2019

\begin{abstract}
This study was conducted to determine the effect of honey addition on the kefir qualities as therapeutic drink. A completely factorial randomized design with two factors was used in this study. The first factor is the starter concentration (7.5 and 15\%), and the second factor is the honey concentration (0, 4 and 8\%) on kefir, with each treatment was done 3 times. The observed parameters were kefir $\mathrm{pH}$, protein content, total microbial, antibacterial and antioxidant levels. The results showed that the usage of honey had a very significant effect $(P<0.01)$ on the kefir $\mathrm{pH}$ and protein content, but did not affect the total microbial, antibacterial and antioxidant activity. Furthermore, the combination of $15 \%$ starters and $4 \%$ honey significantly $(P<0.01)$ increase the protein content and antioxidant activity. Honey addition as much as 4 and $8 \%$ was able to increase the kefir $p H$ value in the range of 3.60 to 3.77 with starter concentration at 7.5 and $15 \%$. The antioxidant activity was increased at the combination of $15 \%$ starters and $4 \%$ honey, while the total microbial was increased at all of the honey addition levels. Moreover, kefir showed an antibacterial activity against Escherichia coli and Staphylococcus aureus in all treatments. In conclusion, 4\% honey addition has the potential to improve the kefir quality and enhance its characteristics as therapeutic drink with $15 \%$ starters concentration.
\end{abstract}

Keywords: Honey; kefir; antioxidants; antimicrobial 


\begin{abstract}
ABSTRAK
Penelitian telah dilakukan tentang manfaat madu sebagai salah satu senyawa yang dapat meningkatkan kualitas kefir. Tujuan penelitian ini adalah ingin mengetahui pengaruh penambahan madu tehadap kualitas kefir sebagai minuman yang bersifat terapeutik. Rancangan Acak lengkap pola faktorial digunakan dalam penelitian ini yang terdiri dari dua faktor masing-masing faktor A adalah persentase starter yang terdiri dari 2 level yaitu 7,5 dan 15\%, faktor B adalah persentase madu yang terdiri dari 3 level yaitu 0, 4 dan $8 \%$ serta setiap perlakuan diulang sebanyak 3 kali. Parameter yang diamati antara lain $p H$, kadar protein, aktivitas antioksidan total mikroba dan aktivitas antibakteri. Hasil penelitian menunjukkan bahwa penggunaan madu berpengaruh sangat nyata $P(<0,01)$ terhadap $p H$ kefir dan kadar protein, namun tidak berpengaruh terhadap total mikroba, antibakteri dan aktivitas antioksidan. Interaksi antara $15 \%$ starter dan $4 \%$ madu sangat nyata $(P<0,01)$ meningkatkan kadar protein dan aktivitas antioksidan. Penambahan madu mampu menigkatkan nilai pH pada kisaran 3,60 sampai 3,77, pada level starter 7,5 dan 15 pada 4 dan $8 \%$ madu. Aktivitas antioksidan meningkat pada $15 \%$ starter dan $4 \%$ madu, sedangkan total mikroba meningkat pada persentase starter yang sama tetapi pada semua level penambahan madu. Kefir menunjukkan memiliki aktivitas antibakteri terhadap bakteri uji Eschericia coli dan Staphylococcus aureus pada semua perlakuan. Kesimpulannya adalah madu memiliki potensi sebagai agent yang dapat meningkatkan kualitas dan menambah karakteristik kefir sebagai minuman yang bersifat terapeutik pada level 15\% starter dan $4 \%$ madu
\end{abstract}

Kata kunci: Madu; kefir; antioksidan; antimikroba

\section{PENDAHULUAN}

Kefir adalah minuman susu fermentasi yang dihasilkan oleh aktivitas bakteri asam laktat dan khamir yang terkandung pada biji kefir serta memiliki rasa yang unik dan khas. Kefir merupakan salah satu produk olahan susu fermentasi yang berbeda dengan yogurt dalam hal komposisi starter dimana yogurt hanya terdiri dari bakteri asam laktat dan tidak mengandung khamir. Kefir saat ini sudah dikenal masyarakat sebagai produk yang memiliki rasa dan aroma yang khas dan bermanfaat bagi kesehatan serta difermentasi oleh bakteri asam laktat seperti Lactobacillus lactis dan Lactobacillus kefiranofaciens serta khamir
(Sudarwanto 2005; Guzel-Seydim 2011). Beberapa keuntungan dari sifat terapeutik kefir ini antara lain seperti antikarsinogenik (Furukawa et al., 2000); antioksidan (Liu et al., 2005); antibakteri (Yuksekdag et al., 2004) dan antiimflamasi (Moreira et al., 2008). Selain itu kefir juga dapat menyehatkan pencernaan, menyeimbangkan mikroflora usus serta mikroorganisme yang dikandungnya mampu berkolonisasi di dalam usus (Vinderola et al., 2006)

Fermentasi susu menjadi kefir menghasilkan senyawa metabolit yang bermanfaat bagi kesehatan dan memiliki efek terapeutik dengan sifat antibakterinya seperti asam organik, karbondioksida, hidrogen peroksida, etanol, diasetil dan
*Corresponding author:

Yurliasni

Email: yurliasni62@gmail.com

Program Studi Peternakan, Fakultas Pertanian, Universitas Syiah Kuala, Banda Aceh, 23111, Indonesia
How to cite:

Yurliasni., Hanum, Z., \& Hikmawan, R. (2019). Potensi Madu dalam Meningkatkan Kualitas Minuman Kefir. Jurnal Ilmu dan Teknologi Hasil Ternak, 14 (1), 50-59 
peptida (bakteriosin) ( Simova et al., 2009). Potensi kefir sebagai pangan fungsional akan lebih berkembang apabila dikombinasikan dengan produk alami lain yang tujuannya adalah meningkatkan kualitas dan efektivitasnya sebagai minuman kesehatan, dalam hal ini salah satunya adalah dengan penambahan madu. Puspitasari (2007) menjelaskan bahwa madu merupakan larutan gula dengan saturasi tinggi mengandung enzim katalase serta memiliki efek antibakteri.

Penambahan madu diharapkan lebih meningkatkan dan memperbaiki kualitas kefir sebagai minuman, selain mengandung berbagai jenis gula, seperti $41 \%$ fruktosa, $35 \%$ glukosa dan 1,9\% sukrosa madu juga mengandung vitamin $\mathrm{A}, \mathrm{B} 1, \mathrm{~B} 2, \mathrm{~B} 3, \mathrm{~B} 5, \mathrm{~B} 6, \mathrm{C}, \mathrm{D}, \mathrm{E}, \mathrm{K}, \beta$ karoten, flavonoid, asam fenolik dan asam nikotinat serta mengandung mineral, garam dan zat lain seperti: besi, sulfur, magnesium, kalsium, kalium, khlor, natrium, fosfor, sodium dan antibiotika serta enzim pencernaan. Persentase madu dan starter kefir merupakan faktor yang sangat penting diperhatikan untuk menghasilkan kualitas kefir sebagai minuman yang bersifat terapeutik. Proses fermentasi akan menurunkan $\mathrm{pH}(3,6-4,5)$, meningkatkan kadar protein, antioksidan, total mikroba $\left(10^{8} \mathrm{cfu} / \mathrm{ml}\right)$ dan aktivitas antibakteri kefir. Karakteristik kefir yang dihasilkan memiliki pH 4,2 sampai 4,6 (Fanworth, 2008), kandungan protein 3,3 sampai 3,5\% (Sarkar 2008), total mikroba $10^{8} \mathrm{cfu} / \mathrm{ml}$ dan memiliki aktivitas antioksidan (Chen et al.,, 2015). Penelitian ini bertujuan mempelajari potensi madu meningkatkan kualitas kefir sebagai minuman yang bersifat terapeutik.

\section{MATERI DAN METODE}

\section{Pembuatan kefir}

Persiapan kefir diawali dengan menghitung kandungan bakteri asam laktat dan khamir yang terdapat pada biji kefir yang digunakan dan komposisinya adalah bakteri asam laktat $1,48 \times 10^{7} \mathrm{cfu} / \mathrm{g}$ dan khamir $7,7 \quad$ x $10^{5}$ cfu/g. Selanjutnya pembuatan kefir dilakukan berdasarkan penelitian Chandan, dkk. (2006). Botol sampel steril yang telah disiapkan diisi dengan $250 \mathrm{ml}$ susu kambing yang sudah dipasteurisasi pada suhu $90-95^{\circ} \mathrm{C}$, kemudian di inokulasi menggunakan starter kefir sebanyak 7,5 dan $15 \%$ (v/v) dan penambahan madu (madu Nusantara) masing-masing sebanyak 0,4 , dan $8 \%$ (v/v), diinkubasi pada suhu $30^{\circ} \mathrm{C}$ selama 24 jam dan selanjutnya disimpan pada suhu $4^{0} \mathrm{C}$. Madu yang digunakan dalam penelitian ini memiliki kadar gula $1,40 \%$ berdasarkan SNI Nomor 01-3545 Tahun 2013, jumlah karbohidrat yang ada pada madu adalah dalam bentuk gula pereduksi dengan kandungan minimal $65 \%$

\section{Pengukuran pH}

$\mathrm{pH}$ sampel diukur menggunakan AZ pH-meter. Elektroda dibilas dengan aquades dan dikeringkan dengan kertas tissue, selanjutnya elektroda dicelupkan pada sampel dan $\mathrm{pH}$-meter diset pada pengukuran $\mathrm{pH}$, elektroda dibiarkan beberapa saat sampai jarum $\mathrm{pH}-\mathrm{meter}$ stabil dan menunjukkan $\mathrm{pH}$ sampel.

\section{Analisis Kadar Protein (Metode Formol)}

Prinsip metode formol adalah untuk menentukan kadar protein terlarut dalam suatu bahan, khususnya susu fermentasi. Standar, ditimbang sampel sebanyak $25 \mathrm{ml}$ dimasukkan ke dalam gelas Erlenmeyer, ditambahkan $1 \mathrm{ml}$ larutan kalium oksalat dan ditambahkan 0,1 ml larutan kobal sulfat. Sampel (V1), $25 \mathrm{ml}$ sampel dimasukkan ke dalam erlenmayer, ditambahkan $1 \mathrm{ml}$ larutan kalium oksalat, ditambahkan 0,25 $\mathrm{ml}$ larutan phenolpthalin, diamkan selama 2 menit, titrasi dengan $\mathrm{NaOH} 0,1 \mathrm{~N}$ sampai warna merah jambu. Masukkan $2 \mathrm{ml}$ formaldehid dihomogen sampai warna merah muda menghilang, biarkan selama 1 menit. Titrasi dengan $\mathrm{NaOH} \quad 0,1 \quad \mathrm{~N}$ sampai berwarna merah standar (merah jambu). Blangko (V2) pengujian dibuat dengan menggantikan sampel dengan aquades sebanyak $10 \mathrm{ml}$ 
dimasukkan ke dalam erlenmayer, tambahkan $1 \mathrm{ml}$ larutan kalium oksalat. Masukkan 0,5 ml larutan phenolpthalein, diamkan selama 2 menit. Titrasi dengan $\mathrm{NaCl} 0,17 \mathrm{~N}$ sampai warna merah jambu, ditambahkan $2 \mathrm{ml}$ formaldehid dihomogenkan, warna merah muda menghilang, biarkan selama 1 menit selanjutnya dititrasi dengan $\mathrm{NaOH} 0,17 \mathrm{~N}$ sampai berwarna merah standar (merah jambu).

Kadar Protein $=$ V1- V2 X 1,83

Keterangan:

$\mathrm{V} 1=\mathrm{ml} \mathrm{NaOH}$ sampel

$\mathrm{V} 2=\mathrm{ml} \mathrm{NaOH}$ blanko

$\mathrm{Fk}=$ Faktor koreksi (susu kambing)
Aktivitas Antioksidan

Aktivitas antioksidan ditentukan menggunakan metode DPPH Radical Scavenging Method (Batubara et al., 2010). Sampel kefir sebanyak 0,2 ml ditambahkan larutan DPPH 3,8 ml yang dilarutkan dalam methanol sampai muncul warna ungu pada sampel. Metanol digunakan sebagai blanko yang diperlakukan sama seperti sampel. Selanjutnya sampel di homogenkan menggunakan vortex, diinkubasi di ruang gelap selama 30 menit dan selanjutnya dengan spectrophotometer pada gelombang 517 absorbansinya dapat dibaca Penentuan aktivitas antioksidan menggunakan rumus berikut.

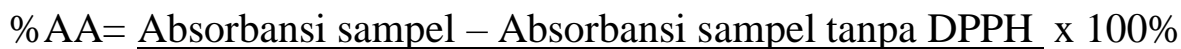

Absorbansi kontrol

\section{Total Mikroba}

Menghitung total mikroba menggunakan metode spread-plate count dan ukuran sampel hanya menggunakan 0,1 mL (Adams and Moss 2008) dan untuk menentukan jumlah total koloni mikroba yang tumbuh dinyatakan dalam cfu $\mathrm{mL}^{-1}$ setelah menginokulasikan sampel sebanyak $0,1 \mathrm{~mL}$ dari pengenceran $10^{-6}$ dan $10^{-7}$ pada media nutrien agar dan di inkubasi selama 24 jam.

\section{Uji Aktivitas Antibakteri (Uji hambat)}

Aktivitas antibakteri ditandai dengan terbentuknya zona hambat sebagai respon oleh bakteri uji. Metode yang digunakan adalah metode kertas cakram (disc diffusion). Diinokulasikan sebanyak $10^{-3}$ masing-masing bakteri uji ke dalam media nutrient agar (E. coli) media Vogel Jonson Agar S.aureus). Kertas cakram yang sudah direndam di dalam sampel kemudian diletakkan dipermukaan media agar yang sudah diinokulasi dengan bakteri uji. Discchloramphenicol digunakan sebagai kontrol positif. Selanjutnya diinkubasi pada suhu $37^{\circ} \mathrm{C}$ selama $19-24$ jam.

\section{Rancangan Percobaan}

Rancangan percobaan yang digunakan dalam penelitian ini adalah Rancangan Acak Lengkap Pola Faktorial, yang terdiri dari dua faktor masing-masing faktor A persentase starter kefir yang terdiri dari 2 level 7,5\% dan 15\%; faktor B persentase madu terdiri dari tiga level yaitu 0,4 dan $8 \%$ serta setiap perlakuan diulang sebanyak 3 kali.

\section{Analisis Data}

Data hasil pengukuran $\mathrm{pH}$, kadar protein, total mikroba dan dianalisis menggunakan analisis sidik ragam (ANOVA) dan akan dilanjutkan dengan Uji Jarak Berganda Duncan pada level 0,05 dan 0,01 , sedangkan kadar antioksidan dan antibakteri menggunakan analisis diskriptif.

\section{HASIL DAN PEMBAHASAN}

\section{Nilai pH}

Penggunaan starter dan penambahan madu dengan persentase yang berbeda berpengaruh sangat nyata $(\mathrm{P}<0,01)$ terhadap nilai $\mathrm{pH}$ kefir, akan tetapi tidak 
terjadi interaksi antara perlakuan. Tidak ada perbedaan $\mathrm{pH}$ pada penggunaan ke dua level starter, namun terjadi perbedaan yang sangat nyata pada penambahan madu. Hal ini dapat dilihat pada Gambar 1. Pada perlakuan $7,5 \%$ starter tanpa penambahan dan penambahan madu $4 \%$ menunjukkan $\mathrm{pH}$ tidak berbeda akan tetapi lebih rendah dan berbeda sangat nyata dengan penambahan $8 \%$ madu yaitu 3,71. Selanjutnya pada starter $15 \%$ terlihat peningkatan $\mathrm{pH}$ sejalan dengan meningkatnya persentase madu yaitu masing 3,71 pada tanpa penambahan madu dan 3,75 pada $8 \%$ madu, namun terjadi penurunan pada $4 \%$ madu yaitu 3,64 . Hal ini menunjukkan bahwa penambahan madu mampu meningkatkan dan menurunkan nilai $\mathrm{pH}$ kefir selama proses fermentasi. Menurunnya nilai $\mathrm{pH}$ kefir berhubungan dengan pemanfaatan karbohidrat dalam hal ini laktosa dalam bentuk glukosa dan galaktosa serta sumber karbohidrat asal madu diantaranya glukosa dan fruktosa yang secara optimal sudah digunakan oleh bakteri asam laktat dan khamir sebagai sumber energi bagi pertumbuhannya. Penurunan $\mathrm{pH}$ juga ditentukan oleh peningkatan jumlah mikroba dan perombakan senyawa-senyawa gula menjadi asam-asam organic (Greenwalt et al., 2006).

Sejalan dengan hasil penelitian Lengkey et al., ( 2013) yang menyatakan bahwa nilai $\mathrm{pH}$ kefir akan semakin rendah dengan meningkatnya jumlah starter yang digunakan, disebabkan oleh aktivitas mikroba yang merombak laktosa menjadi asam laktat dan asam-asam organik lainnya.

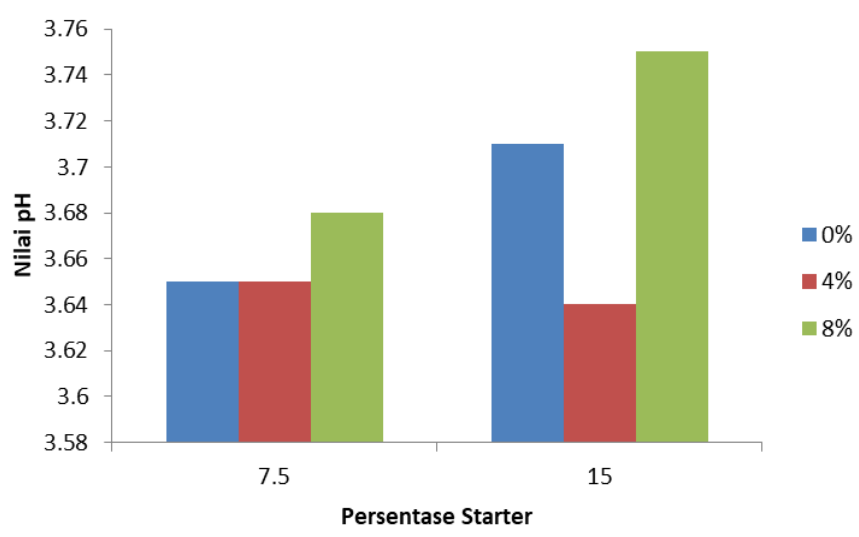

Gambar 1. Kurva perubahan $\mathrm{pH}$ kefir dengan penggunaan starter dan penambahan madu pada persentase yang berbeda

Selanjutnya selama proses fermentasi terjadi peningkatan $\mathrm{pH}$ pada kedua level persentase strater pada penambahan madu 8 persen yaitu masing masing 3,68 dan 3,75, akan tetapi Peningkatan $\mathrm{pH}$ ini terjadi diduga interaksi berupa simbiosis yang kompetitiv diantara bakteri asam laktat dan khamir sehingga pertumbuhan lebih didominasi oleh khamir dan metabolisme karbohidrat berjalan kearah diproduksinya etanol dan karbondioksida oleh khamir sebagai hasil pemecahan glukosa dan galaktosa (Amparo and Fleet, 2006)

\section{Kadar Protein}

Penambahan madu dan starter kefir dengan persentase yang berbeda berpengaruh sangat nyata $(\mathrm{P}<0,01)$ terhadap kadar protein kefir yang dihasilkan dan terjadi interaksi antara ke dua faktor perlakuan. Hal ini di dukung dengan hasil analisis data yang diperoleh yang dapat dilihat pada Gambar 2.

Grafik ini menunjukkan bahwa kadar protein kefir tanpa penambahan madu pada kedua level starter tidak berbeda nilai yang sama yaitu 3,29\% demikian juga dengan penambahan madu 
$4 \%$ dan $8 \%$ yaitu 2,68 dan $2,56 \%$. Sebaliknya penggunaan $15 \%$ starter dengan penembahan $4 \%$ madu berbeda sangat nyata dengan tanpa penambahan dan penambahan madu $8 \%$ yaitu $4,51 \%$ dibandingkan dengan 3,29 dan 2,92\% Hal ini menunjukkan bahwa pada kondisi ini pertumbuhan mikroba kefir optimal sehingga hampir sebagian besar protein yang dikandung oleh kefir dapat dicerna menjadi senyawa yang lebih sederhana dalam bentuk $\mathrm{N}$ terlarut.

Bakteri asam laktat akan tumbuh secara optimal apa bila ketersediaan nutrisinya terpenuhi sehingga dapat tumbuh dengan jumlah sel yang tinggi. Hasil ini sejalan dengan penelitian yang dilakukan Bottazi (2003), bahwa pada proses fermentasi susu pertumbuhan mikroba dapat meyumbangkan proteinnya sebesar $7 \%$.

\begin{abstract}
Aktivitas Antioksidan
Antioksidan merupakan senyawa bioaktif yang sangat bermanfaat bagi kesehatan dalam mencegah proses penuaan dan penyakit degenerative, karena sifatnya yang dapat melawan radikal bebas yang terdapat dalam tubuh dan diperoleh antara lain dari hasil metabolisme makanan, polusi udara, dan cemaran sinar matahari (Shihabi 2009).
\end{abstract}

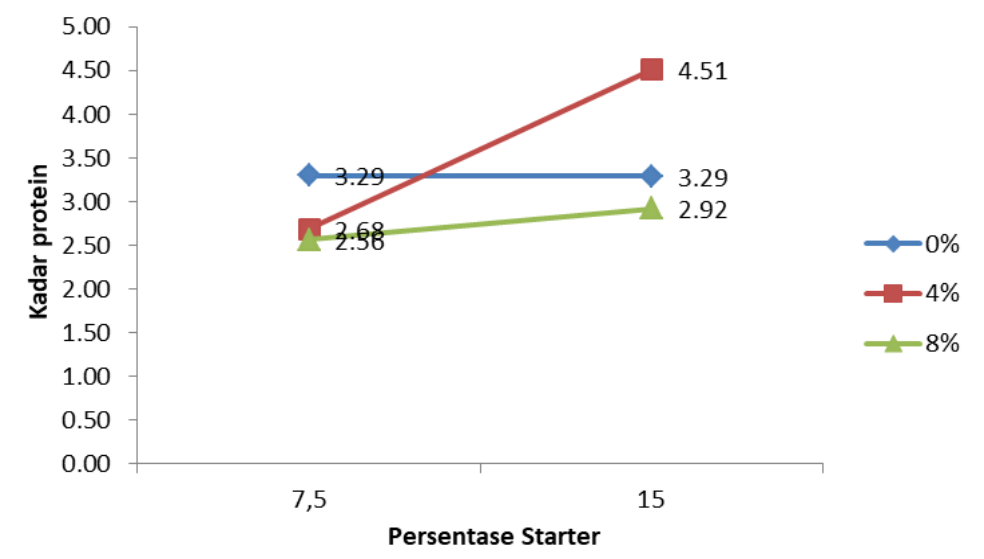

Gambar 2. Grafik interaksi antara level starter dan madu pada persentase berbeda terhadap kadar protein

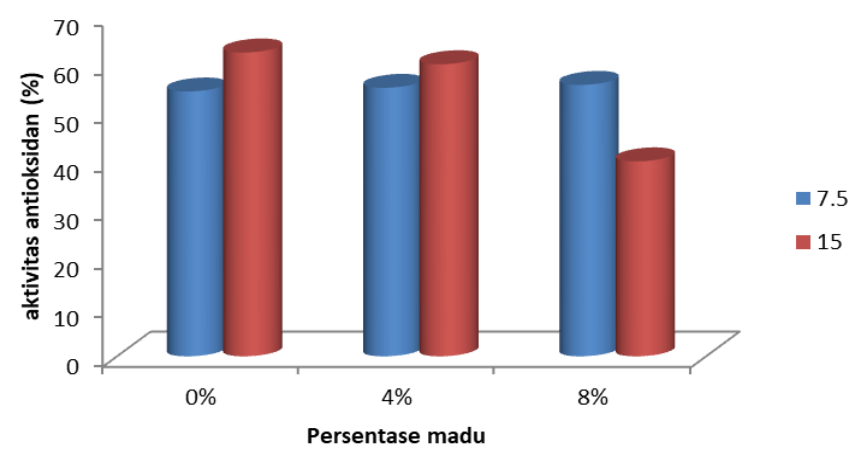

Gambar 3. Grafik aktivitas antioksidan kefir dengan penambahan starter dan madu pada persentase yang berbeda 


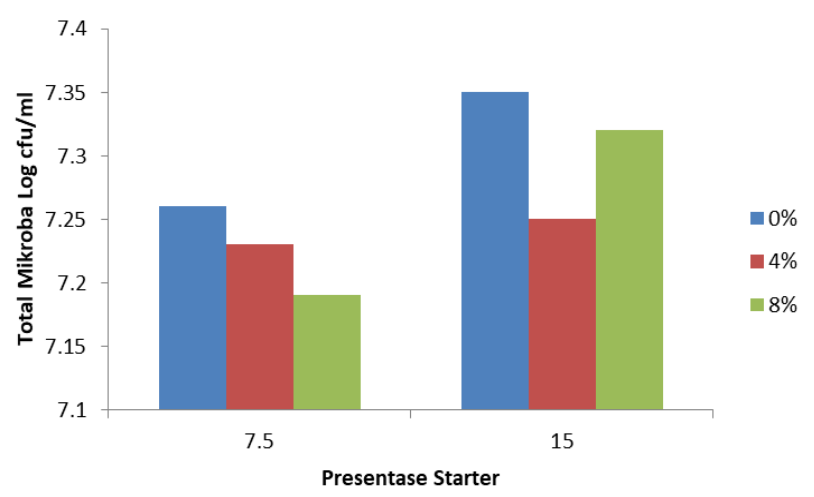

Gambar 4. Grafik total mikroba kefir dengan penambahan starter dan madu pada persentase yang berbeda

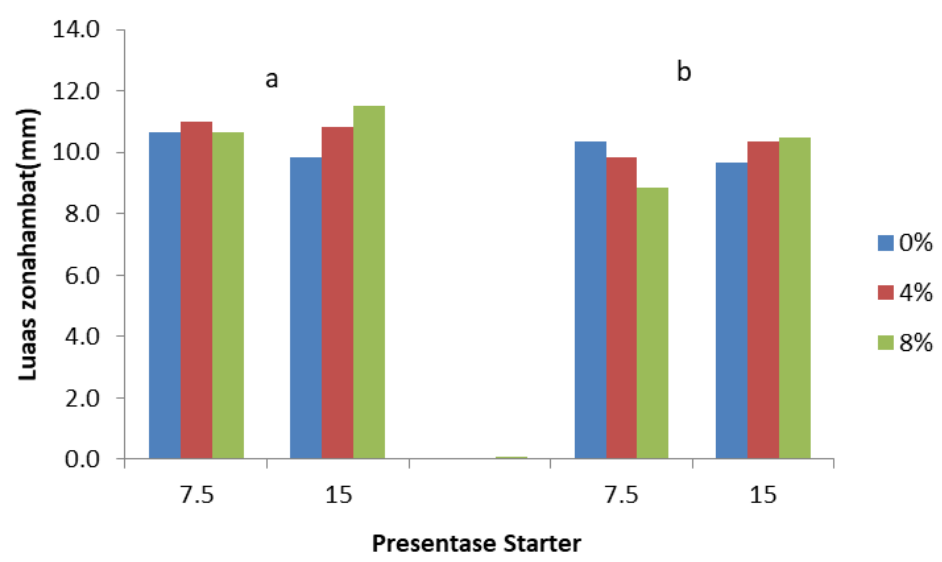

Gambar 5. Grafik luas zona hambat $(\mathrm{mm})$ kefir dengan penambahan starter dan madu pada persentase yang berbeda Keterangan: a) E. Coli; b) S.aureus

Berdasarkan hasil analisis aktivitas antioksidan menggunakan metode DPPH, diperoleh nilai seperti yang tergambar pada Gambar 3. Aktivitas antioksidan pada kefir dengan penggunaan starter $7,5 \%$ menunjukan nilai yang hampir sama pada semua level penambahan madu $(54,868$; 55,219; 55,825) akan tetapi pada penggunaan $15 \%$ starter terlihat semakin tinggi penambahan madu maka kadar antioksidannya semakin meningkat yaitu pada tanpa penambahan dan penambahan $4 \%$ madu.

Aktivitas antioksidan meningkat diduga akibat terbentuknya asam-asam organik yang diproduksi oleh bakteri asam laktat dan khamir yang bersifat sinergis dengan memberikan ion $\mathrm{H}^{+}$pada radikal bebas. Sebaliknya aktivitas antioksidan memperlihatkan penurunan pada $8 \%$ madu yaitu $(62,481 ; 60,061 ; 40,091)$. Hal ini berhubungan dengan interaksi antara bakteri asam laktat dan khamir yaitu simbiosis kompetitif dimana perumbuhan bakteri asam laktat lebih mendominasi sehingga mampu menggunakan nutrisi yang tersedia untuk pertumbuhannya karena tersedianya sumber energi dalam jumlah yang tinggi.Ishandayani dan Mustafik (2006) menjelaskan bahwa menurunnya antioksidan selama fermentasi diduga akibat digunakan oleh mikroba baik bakteri asam laktat maupun khamir dan rusaknya antioksidan akibat oksidasi oleh hydrogen peroksida yang dihasilkan oleh bakteri asam laktat dan alkohol oleh khamir.

Berdasarkan hal tersebut maka penambahan madu pada kefir harus dibatasi sampai persentase yang menghasilkan 
kadar antioksidan yang optimal, karena penambahan madu yang berlebihan dapat menurunkan kadar antioksidan kefir.

\section{Total Mikroba}

Penggunaan starter dan penambahan madu tidak berpengaruh terhadap total mikroba kefir. Total mikroba yang diperoleh pada penggunaan $7,5 \%$ starter dan pada setiap level madu menunjukkan penurunan (Gambar 4.), semakin tinggi penambahan madu maka semakin berkurang total mikroba kefir. Hal ini dapat disebabkan oleh beberapa faktor antara lain sifat madu yang memiliki tekanan osmotik yang tinggi, dan kandungan beberapa senyawa bioaktiv seperti asam format dan hydrogen peroksida yang mampu menekan pertumbuhan mikroba (Mundo, 2004) Sebaliknya total mikroba terlihat meningkat pada penggunaan $15 \%$ starter untuk setiap level madu.

Kondisi ini menjelaskan bahwa telah terjadi interaksi yang sangat baik antara mikroba yaitu antara bakteri asam laktat dan khamir yang terdapat dalam kefir. Interaksi yang terjadi adalah simbiosis mutualisme dimana pertumbuhan bakteri asam laktat tergantung kepada metabolit yang dihasilkan oleh khamir dan demikian sebaliknya, sehingga mikroba dapat tumbuh secara optimal dengan sumber energy yang tersedia (Amparo and Fleet, 2006).

\section{Aktivitas Antibakteri}

Aktivitas antimikroba yang dihasilkan susu fermentasi dapat dikaitkan dengan produksi metabolit akhir atau senyawa antibakteri yang dihasilkan oleh starter. Gambar 5 menunjukkan tidak ada perbedaan yang nyata pada luas zona hambat yang terbentuk. Luas zona hambat yang terbentuk pada kedua bakteri uji berkisar antara $8,8 \mathrm{~mm}$ sampai $11,5 \mathrm{~mm}$. Semakin tinggi persentase penggunaan dan penambahan madu memperlihatkan luas zona hambat yang lebih luas.
Zona hambat yang terbentuk pada E.coli terlihat lebih luas pada level $15 \%$ starter dan $8 \%$ madu yang mencapai $11,5 \mathrm{~mm}$, dan hal ini selaras dengan total mikroba diperoleh selama fermentasi kefir. Demikian juga halnya zona hambat yang terbentuk pada S.aureus dengan luas sebesar 10,5 mm. Hasil ini menjelaskan bahwa kefir memiliki aktivitas antimikroba baik terhadap Gram positif maupun Gram negatif. Sejalan dengan penelitian Czamanski et al. (2004) yang menyatakan bahwa kefir memiliki efek bakteriostatik yang lebih tinggi terhadap gram negatif tetapi efek bakterisida yang lebih baik terhadap organisme Gram positif. Mundo (2004) menyatakan bahwa kemampuan antibakteri ini juga berhubungan dengan senyawa bioaktif yang dimiliki madu seperti fenol dan flavonoid yang berperan sebagai antioksidan yang sekaligus dapat menekan pertumbuhan bakteri Gram positif dan Gram negatif.

Beberapa penelitian yang terdahulu menyatakan bahwa kefir merupakan produk terapeutik yang dapat dikonsumsi dengan aman dan menunjukkan bahwa banyak lactobacilli mampu menghasilkan berbagai komponen antimikroba termasuk asam organik, karbondioksida, hidrogen peroksida, etanol, diasetil dan peptida. Komponen-komponen ini mungkin bermanfaat tidak hanya dalam pengurangan patogen bawaan makanan dan bakteri pembusuk selama produksi dan penyimpanan, tetapi juga dalam perawatan dan pencegahan gangguan gastrointestinal (Liu et al., 2008; Simova et al., 2009).

\section{KESIMPULAN}

Penambahan madu berpotensi meningkatkan kualitas serta menambah karakteristik kefir sebagai produk fermentasi yang bersifat terapeutik. Penambahan madu yang optimal adalah pada level $4 \%$ dan penggunaan starter $15 \%$. 


\section{DAFTAR PUSTAKA}

Adam, M. R., \& Moss, R. O. (2008). Food Microbiology (3rd ed.). Cambridge: RSC Pub.

Amparo, Q., \& Fleet, G. H. (2006). Yeast In Food and Beverages (2nd ed.). Springer: The Yeast Hand Book.

Batubara, I. L., Darusman, T., Mitsunaga, M., Rahminiwati, M., \& Djauhari, E. (2010). Potency of indonesia meedicinal plant as tyrosinase inhibitors antioxidant agent. Jurnal Biology Science, 10(2), 138-144.

Bottazi, V., Zacconi, C., Sarra, P. G., Dallvalle, P., \& Parisi, M. G. (2003). Kefir microbiologia, chimica, etecnologia. Lindustria Latte, 30, 41-62.

Bozanic, R., \& Tratnik, L. (2001). Quality cow's and goat's fermented bifido milk during storage. Food Technol. Biotechnol, 39(2), 109-114.

Cabeen, M. T., \& Jacobs, W. (2005). Bacterial Cell Shape. Nat. Rev. Microbiology.

Chandan, R., White, C., Kilara, A., \& Hui, Y. (2006). Manufacturing Yogurt and Fermented Milk. UK: BleckWell Publishing.

Chen, Z., Shi, J., Yang, X., Nan, B., Liu, Y., \& Wang, Z. (2015). Chemical and physical characteristics and antioxidant activities of the exopolysaccharide produced by Tibetan kefir grains during milk fermentation. International Dairy Journal, 43, 15-21. https://doi.org/10.1016/J.IDAIRYJ.2014.10.004

Czmanski, R. T., Greco, D. P., \& Wiest, J. M. (2004). Evaluation of antibiotic activity in filtrates of traditional kefir. Higiene Alimentar, 18, 75-77.
Farnworth, E. (2008). Handbook of Fermented Functional Foods (2nd ed.). New York: Eds.CRC Press.

Farnworth, E. R. (2005). Kefir. A complex probiotics. Food research and development centre agriculture and agrifood canada J2S8E3 food science and technology. Bulletin Functional Food, 2(1), 1-17.

Greenwalt, C. J., Ledford, R. A., \& Steinkrause, K. H. (2006). Determination And of The Characterization of The Antimicrobial Activity Fermented Tea Combucha. New York: Departement of Food Science Cornel University.

Guzel-Seydim, Z. B., Kok-Tas, T., Greene, A. K., \& Seydim, A. C. (2011). Review: Functional Properties of Kefir. Critical Reviews in Food Science and Nutrition, 51(3), 261-268. https://doi.org/10.1080/10408390903579029

Handayan, I., \& Mustaufik. (1992). Penggunaan campuran bakteri asam laktat dan khamir sebagai flavouring agent pada sari buah mengkudu terfermentasi. Pembangunan Pedesaan, 6(3).

Liu, G., Lv, Y., Li, P., Zhou, K., \& Zhang, J. (2008). Pentocin 31-1, an antiListeria bacteriocin produced by lactobacillus pentosus 31-1 isolated from xuan-wei ham, a traditional china fermented meat product. Food Control, 19(4), 353-359. https://doi.org/10.1016/j.foodcont.2007.04.010

Mundo, M. A., Padilla-Zakour, O. I., \& Worobo, R. W. (2004). Growth inhibition of foodborne pathogens and food spoilage organisms by select raw honeys. International Journal of Food Microbiology, 97(1), 1-8. https://doi.org/10.1016/j.ijfoodmicro.2004.03.025 
Nofrianti, R., Azima, F., \& Eliyasmi, R. (2013). Pengaruh penambahan madu terhadap mutu yoghurt jagung (Zea mays Indurata). Jurnal Aplikasi Teknologi Pangan, 2(2).

Shafiee, G., Mortazavian, M., Mohammadifar, M. A., Koushki, M. R., Mohammadi, A., \& Mohammadi, R. (2010). Combined effects of dry matter content, incubation temperature and final ph of fermentation on biochemical and microbiological characteristics of probiotic fermented milk. African Journal of Microbiology Research, 4(12), 1265-1274.

Shihabi, A., Li, W.-G., Miller, F. J., \& Weintraub, N. L. (2002). Antioxidant therapy for atherosclerotic vascular disease: the promise and the pitfalls. American Journal of Physiology-Heart and Circulatory Physiology, 282(3), 797-802. https://doi.org/10.1152/ajpheart.2002.282.3.H797

Simova, E., Beshkova, D., \& Dimitrov, Z. (2009). Characterization and antimicrobial spectrum of bacteriocins produced by lactic acid bacteria isolated from traditional Bulgarian dairy products. Journal of
Applied Microbiology, 106(2), 692-701. https://doi.org/10.1111/j.1365-2672.2008.04052.x

Standar Nasional Indonesia. (2013). Madu. Badan Standarisasi Nasional Indonesia.

Sudarwanto, E. (2005). Dasar pengolahan susu dan hasil ikutan ternak. Jurnal Program Studi Produksi Ternak.

Sunarlim, R., \& Setiyanto, H. (2007). Pengaruh Kombinasi Starter Bakteri Lactobacillus bulgaricus, Streptococcus thermophilus dan Lactobacillus plantarum terhadap Sifat MutuSusu Fermentasi Susu Sapi. Bogor: Seminar Nasional Teknologi Peternakan dan Veteriner.

Susilorini, T. E., \& Sawitri, M. E. (2007). Produk olahan susu. Depok: Penebar Swadaya.

Yüksekdağ, Z., Beyatli, Y., \& Aslim, B. (2004). Determination of some characteristics coccoid forms of lactic acid bacteria isolated from Turkish kefirs with natural probiotic. $L W T$ Food Science and Technology, 37(6), 663-667. https://doi.org/10.1016/j.lwt.2004.02.004 